\title{
THE NEGRO GHETTOS AND FEDERAL HOUSING POLICY
}

\author{
George W. Grier*
}

The summer racial disturbances which have recently become epidemic have focussed attention upon the United States' most important and perplexing domestic problem-rampant racial ghettoization of its major cities. The Negro ghettos are to a considerable degree a product of American housing policies of the post-World War II era. Ironically, they now stand as one of the greatest obstacles to achievement of the nation's goal of decent housing for all its citizens.

These racial concentrations-which are also concentrations of the most deprived of all Americans in virtually every sense of the term-are of impressive size. Today the Negro populations of at least five major cities are estimated to exceed half a million. Negroes constitute close to two-thirds of all residents of Washington, D.C.; more than one-third of the citizens of Baltimore and New Orleans; over one-fourth of those residing in Philadelphia, Detroit, Cleveland, and St. Louis. ${ }^{1}$ In all cases they are compressed into limited areas, while large sections of the same cities remain almost exclusively white. In some places like New York and Los Angeles, where the Negro proportions are somewhat smaller, other severely disadvantaged groups like Puerto Ricans and Mexican-Americans are similarly ghettoized in large numbers.

The recent rate of growth of the urban ghettos can best be described as explosive. During the r95os alone the Negro population of New York increased by forty-six per cent; of Detroit by sixty per cent; of Los Angeles by ninety-six per cent; of Milwaukee by a staggering 187 per cent. ${ }^{2}$ Such rapid increase in a problem-ridden population, together with its compression into areas of the central cities which are most deficient in housing and other facilities and services, helps explain why every one of these cities has recently suffered destructive racial violence.

Today, violence is only the most extreme and obvious symptom of the problems which the slum ghettos are causing the major cities and this nation. Washington, D.C., where ghettoization has proceeded farthest of any, affords some illustrative statistics. ${ }^{3}$ In the twelve years between 1954 and I966, Washington's total population

\footnotetext{
* Senior Associate, Washington Center for Metropolitan Studies, Washington, D.C. Author, Tre Changing Age Profile: Implications for Policy Planning in Metropolitan Washington (1964), [with Eunice S. Grier] Equality and Beyond: Housing Segregation in the Great Society (I966), Privately Developed Interracial Housing ( 1960 ), Discrimination in Housing: A Handeoor of FAct (ig60), Negroes in Five New York Cities (1958).

${ }^{1}$ See generally Grier \& Grier, Obstacles to Desegregation in Housing, 6 RAcE 3 (1964), for a detailed discussion of recent population shifts and their bearing on racial patterns of residence.

${ }^{2}$ Id. at 4 .

${ }^{3}$ These statistics are drawn from the Application for a Federal Grant to Plan for a Model Neighborhood in the District of Columbia, submitted to the U.S. Deparement of Housing and Urban Development by the government of the District of Columbia, April 1967 .
} 
held virtually constant at about 800,000 while its Negro population increased from somewhat over one-third of that total to about two-thirds. During the same period, Washington's public school enrollment increased by almost fifty per cent. Its public assistance caseload rose from 7,500 to Ir,400 despite stringent restrictions upon welfare eligibility. The number of authorized policemen was increased from 2300 to $3^{100}$; but the crime rate rose even faster, elevating Washington to the unenviable position of one of the most crime-ridden of American cities.

Today, Washington has one of the highest venereal disease rates of any major city, and rates of infant mortality and school retardation exceeding many of the most backward states of the Union. In response to the problems the municipal budget has been forced steadily upward, virtually doubling in the last seven years alone. Yet the city still faces pressing shortages of facilities and services of virtually every type to serve the needs of a population which grows increasingly unable to meet the costs.

One of these shortages is a critical lack of decent housing within the economic means of Washington's low-income families. A recent study by the National Capital Planning Commission ${ }^{4}$ estimated that half of the city's household population is unable to afford sound, uncrowded rental housing at the prices which prevail in the private market. Almost no new housing is being constructed for this segment of the population; and private rehabilitation and luxury apartment-house construction in the central district continue to chip away at the existing supply priced within their capacity to pay. Meanwhile, the overall condition of the city's housing stock is believed by expert sources to be deteriorating under the pressure of overcrowding and "slumlord" exploitation. Washington's ghettos thus grow not only blacker but more ill-housed with every passing year.

Quite clearly, the needs and problems of Washington's Negro slums have already surpassed the city's ability to cope with them. Even massive infusions of federal grant funds-now exceeding roo million dollars a year-have failed to close the growing gap between needs and available resources, not to mention reversing the tide of deterioration.

Is Washington, which first passed the fifty per cent mark in Negro proportion at the I 960 Census, merely the prototype for a number of other major cities-including Baltimore, Cleveland, Detroit, New Orleans, Philadelphia, and St. Louiswhich will probably have Negro majorities by 1980 at the latest? Can the social and physical blight of such cities be overcome as long as the ghettos exist? Will the American democratic system itself survive continued political and social upheaval to which the riots of the last several summers may well be only prelude?

One thing at least is becoming clear: solutions will not be simple. The ghettos concentrate human problems and frustrations to a degree which immensely increases

\footnotetext{
‘Problems of Housing People in Washington, D.C. (July ig66) (a special report of the National Capital Planning Commission).
} 
the obstacles to their solution. All the public investment to date in experimental anti-poverty programs, job training, compensatory education, and other approaches has not produced solutions which could be guaranteed to make the racial enclaves within the cities economically and socially viable. Particularly unsettling is the evidence that many of the participants in recent outbreaks of ghetto violence have not been among the most abjectly deprived members of the minority population. A goodly number have been persons who have already climbed a certain way up the long ladder to equality, but who realize how very far and filled with obstacles is the distance remaining. ${ }^{5}$

The pressure of needs upon the resources within the ghettos will continue to grow, for the ghettos themselves will almost certainly keep growing. The reason lies in basic demographic facts. Even if migration of minorities from rural areas to the cities were to cease completely, their rate of natural increase is now sufficient to continue the increase of those groups within the urban centers at a rapid pace. The Negro slum populations are young on the whole, with high concentrations in the teen and early adult years.

On the other hand, the recent exodus of whites from cities to suburbs has been heavily concentrated among families of prime childbearing age. Thus, the whites left in the cities tend increasingly to be past the age where they can increase their numbers. Again to cite an example from the nation's capital city, two-thirds of the white adult population of Washington is now past the age of forty. ${ }^{6}$ It does not require clairvoyance to foresee that Washington's Negro population will continue to increase rapidly both in numbers and in proportion to the whole.

Thus, there will be continued consolidation and expansion of the heavily-Negro concentrations until they fill the central cities and extend into the suburbs. At the same time, white resistance to the racial conversion of neighborhoods formerly closed to Negroes can be expected to remain high, especially in the solid, highly-organized ethnic areas which still abound in most northern industrial centers. There will be at least two concomitants: first, the areas of Negro residence will continue to expand less slowly than the need. Second, there will be a continuing high level of racial tension and sporadic open conflict, due both to the bottling-up of Negroes with their needs and frustrations within the ghettos, and to white reactions to the expressions of frustration and the inexorable expansion of ghetto boundaries. The economic viability of central business districts will continue to be threatened as they are surrounded by widening areas of social and economic deprivation and conflict.

These will be the virtually inevitable consequences unless measures of sufficient scope are taken to eliminate the racial ghettos as a feature of the American urban

\footnotetext{
${ }^{-}$See generally R. Conot, Rivers of Blood, Years of Darkness (1967), for an excellent analysis of the origins of the Los Angeles riot.

${ }^{\circ}$ G. Grier, The Changing Age Profile: Implications for Policy Planning in Metropolitan Washringron (Washington Center for Metropolitan Studies, 1964).
} 
landscape, and to replace them with unsegregated patterns of residence. While this will be no easy task, the alternative of a nation both racially divided and continually at war within itself is not a prospect most Americans will accept with equanimity. It is the contention of this article that solutions are possible, albeit difficult. We seek to demonstrate the following points: (I) The racial ghettos are chiefly creatures of public policy, and in large part of housing policy, which fostered and directed their growth into present patterns. (2) To a major degree, the ghettos are also products of the post-World War II era. For example, in 1940 Washington's Negro population was less than half its present size, and was segregated to a much less rigid degree. ${ }^{\top}$ (3) What public policy has created within a single generation, it is equally capable of undoing in a similar span of time. To achieve this, however, will require a massive reorientation of available resources.

First, let us review the contributions of public policy to the emergence of the ghettos. Its role can best be understood when viewed against the background of the major population trends which shaped the development of the nation as a whole during the period of the ghettos' most rapid growth.

One of these forces was a high overall rate of population increase: twenty-eight million people were added to the United States population in the r950s alone. A second was urbanization: about eighty-five per cent of this staggering growth was concentrated in only $2 \times 2$ metropolitan areas, while most rural sections had substantial net out-migrations. ${ }^{8}$

National policy unquestionably helped accelerate the cityward migration by encouraging the development of mechanized agricultural techniques and the consolidation of small family farms into huge agricultural "factories" where mass production methods were most feasible. At the same time, the federal government did little or nothing to encourage the development of smaller towns within largely rural areas. Thus, it became necessary for many of those displaced to move long distances to the major cities in search of employment.

The policy factors mentioned so far were largely neutral in terms of race. However, a disproportionate number of the long-distance migrants, especially in a southto-north direction, were Negro. One reason was that the low-skilled farm workers displaced by mechanization were heavily Negro. A second was less accidental: the traditional discriminatory practices of the south, and the reluctance of the federal government to interfere in these practices, meant that few job opportunities were available for displaced Negro farm workers in southern commerce and industry. Thus, in both positive and negative fashion, public policies and practices paved the route for the Negro migration to the great metropolitan complexes of the north.

\footnotetext{
'E. Grier, Understanding Washington's Changing Population (Washington Center for Metropolitan Studies, I96I).

${ }^{8}$ U.S. Bureau of the Census, Dep't of Commerce, U.S. Census of Population, ig6o; see particularly the special reports in Series PC(2) on migration.
} 
It was after the Negro migrants arrived at northern destinations, however, that public policy played its most decisive role in shaping the ghettos. The prime guiding forces were applied in the housing area. Both at the federal and the local levels, virtually every aspect of housing policy interlocked to encourage the concentration of Negro newcomers within the central city slums, and to prevent their escape once they had begun to climb the economic ladder.

Until recent years, federal policy in housing was mainly supportive of racial segregation. At the very least, it did little to interfere with discriminatory practices by local authorities and private entrepreneurs; at the worst (and particularly before 1950), it actively encouraged such practices. ${ }^{9}$ Not until President Kennedy's landmark Executive Order of November $1962^{10}$ was the federal government placed clearly on record to the effect that racial discrimination in housing was contrary to the national interest.

That presidential directive, even then, may have been more an expression of individual belief than of national policy. Five years later it still had not been backed up by legislation, and a bill strengthening the Civil Rights Act of $1964^{11}$ had failed of enactment in Congress largely because it added housing to the Act's jurisdiction.

Until the late I940s the Federal Housing Administration's Underwriting Manual had advised appraisers to lower their ratings of properties in neighborhoods occupied by "inharmonious racial or nationality groups ... . often to the point of rejection." To assure continuing racial stability in newly developed neighborhoods, it recommended a model restrictive covenant for inclusion in property deeds. A Supreme Court decision of 1948 rendered racial covenants legally unenforceable; but it was not until early in 1950, well into the post-war suburban boom, that FHA ceased insuring new developments covered by them. ${ }^{12}$ Prior to I950, also, FHA's encouragement of segregated development had not been limited to recommending it. Private developers who proposed to build for interracial occupancy were treated to a variety of delaying and obstructing tactics. Some gave up and accepted the requirement of segregation; but in at least two instances, builders who held firmly to nondiscriminatory policies were driven out of business by persistent FHA opposition which prevented them from securing mortgage financing..$^{13}$

In varying ways and to varying degrees, FHA's policies and practices were mirrored by other federal agencies influential in the provision of housing. These included the Public Housing Administration, which encouraged the development of

\footnotetext{
The federal role in enforcing housing discrimination is documented in C. ABRAMs, ForBLDDEN Neighbors (1955).

${ }^{10}$ Exec. Order No. $11,063,3$ C.F.R. 261 (Supp. 1962), 42 U.S.C. $\$ 1982$ (1964).

${ }^{12}$ Pub. L. No. 88-352, 78 Stat. 24 I (codified in scattered sections of 5, 28, 42 U.S.C.).

${ }^{12}$ Shelley v. Kraemer, 334 U.S. I (1948); see C. ABraMrs, supra note 9.

1s See genetally E. Grier \& G. Grier, Privateix Developed Interracial Housing ch. 8 (1960), for detailed case histories of two post-World War II developments intended for interracial occupancy which were driven to financial ruin by FHA opposition despite powerful private support.
} 
segregated projects according to a "racial equity" formula by which units were separately constructed for whites and nonwhites in proportions based on a statistical estimate of relative need. If the needs of the two groups subsequently changed, the allocation of units usually did not. They also included the Veterans Administration, which guaranteed home mortgages for returning veterans, but followed FHA's lead in regard to the kinds of new developments on which those benefits were made available. ${ }^{14}$

In the years following $195^{\circ}$, there was a gradual liberalization of the policies of the federal housing and renewal agencies regarding race; but the changes were specific and limited, and in no sense did the federal government possess a consistent policy against housing discrimination until the rg62 Executive Order.

Under the terms of the Order, FHA and other federal agencies providing housing assistance are required to withhold their aid from builders who discriminate. The coverage of the Order does not extend to housing already on the books before its effective date, or to housing without federal assistance. It is presently estimated that the Order covers only fifteen per cent of new housing, and between two and three per cent of the total housing stock. ${ }^{15}$ Further, the enforcement machinery is basically weak, relying almost exclusively on the compliance machinery of the assisting agencies.

Before the federal prohibition, however, a number of the most populous northern states had adopted laws barring housing discrimination within their jurisdictionsand often having coverage which extended beyond housing receiving governmental aid and into the exclusively private sector. They included such important states as New York, New Jersey, Pennsylvania, Massachusetts, and Michigan.

The number of states possessing such laws has continued to increase, totalling twenty-two as of $1967 .{ }^{16}$ In addition, a number of jurisdictions have progressively broadened the coverage of their initial legislation. While the enforcement mechanisms vary in effectiveness, most are quite weak and cumbersome. But there is little question that in most parts of the United States today, a minority family possessing the will, the perseverance, and adequate financial means can buy or rent housing approximating their preference as to price, size, and style in a fairly wide range of locations outside traditional "ghetto" areas.

\footnotetext{
14 See generally E. Grier \& G. Grier, Equality and Beyond: Housing Segregation in the Great Socrety (1966), for an analysis of the different roles of various federal agencies in denying equal housing opportunity to nonwhites.

${ }^{15}$ This estimate was supplied by the President's Committee on Equal Housing Opportunity.

${ }^{10}$ See generally M. Fisher \& F. Levenson, Federal, State and Local Action Affecting Race and Housing (National Association of Inter-group Relations Officials, I962), for a comprehensive analysis of action at all governmental levels up to the period just before the Ig62 Executive Order. The texts of state and local laws as of the end of r96x are summarized in U.S. Housing and Home Finance Agency, State Statutes and Local Ordinances Prohibiting Discrimination in Housing and Urban Renewal (196r). The most complete and reliable source of up-to-date information on the status of antidiscrimination laws and ordinances throughout the nation is Trends in Housing, published by the National Committee Against Discrimination in Housing.
} 
Does this mean that the problem is well on its way to solution? The answer must be in the negative. At this point in history even the broadest "Fair Housing" legislation, however adequately enforced, would be insufficient to reverse or even to stabilize the growth of the ghettos. Would nondiscrimination in the administration of the programs from their inception have prevented the ghettos from expanding to their present magnitude? However paradoxical it may seem, the answer to this question is also "No"-and for the same reason. The major source of difficulty has never been in discriminatory administration of the federal housing programs. The basic legislative provisions governing the provision of most such benefits assure that the bulk of minority members are unable to take advantage of them, however fairly they are administered.

The entire thrust of federal involvement in the housing field has worked against the availability of federal benefits to deprived minorities such as Negroes. One key lies in the following statement of policy quoted from a recent publication of the U.S. Bureau of the Budget: "The Federal Government encourages better housing for the Nation primarily by assuring the availability of private credit on reasonable terms."17 This emphasis, which derives from the origin of federal housing programs as an economic stimulator in the post-1929 depression, means that the benefits of federal involvement are made available chiefly to those who can pay their own way in the private market.

Most Negroes have automatically been excluded by this fact alone. ${ }^{18}$ Estimation of the proportion of Negro families able to pay private-market prices for new housing is a complicated matter, varying with both income levels and building costs in different localities. Nonetheless, a rough indication of the proportion of Negro families who might be considered candidates for new privately-financed housing is provided by a recent federal report which shows that only twenty-eight per cent of nonwhite families in the United States had incomes of $\$ 7000$ or more in 1966 . During the height of the post-World War II building boom, in the early 1950s, the proportion was much lower-ranging from five to nine per cent adjusted for subsequent price changes. ${ }^{19}$

This fact would be of less moment had supplementary federal aids been made available on a scale sufficient to meet the housing needs of minority families who

\footnotetext{
${ }^{17}$ U.S. Bureau of the Budget, Executive Office of the President, The Budget in Brief, Fiscat. YEAR 1967 , at 42 (Ig66).

${ }^{18}$ While FHA and VA mortgage guarantees enable lower downpayments than are generally available under conventional financing, these are of no help to families whose incomes are too low to meet monthly costs. Interest rates provided through federally-aided mortgages are generally somewhat lower, but not enough to bring costs down to the level affordable by most nonwhites. Limited exceptions will be found in the special subsidy programs to be discussed later in this article as well as the $\$ 221(\mathrm{~h})$ program, 12 U.S.C. $\$ \mathrm{r}_{75} \mathrm{l}(\mathrm{h})$ (Supp. II, $1965-66$ ), which provides low downpayments, and extended (forty year) terms to aid relocated families in purchasing homes.

${ }^{10}$ U.S. Buread of Labor Stattstics, Dep'T of Labor \& U.S. Bureau of the Census, Dep't of Commerce, Social and Economic Condition of Negroes in the United States (BLS Rep. No. 332, Oct. 1967 ).
} 
could not participate in the private market. But such aids have been decidedly limited. Throughout most of the postwar housing boom-during which an average of more than one million new private dwellings were constructed annually-the sole federal resource available to aid in improving the housing of low-income families was the subsidized low-rent public housing program. This program, established under the Housing Act of $1937,{ }^{20}$ employs direct federal subsidies to local housing authorities to achieve rents keyed to capacity to pay.

Three decades after its establishment, at the end of September 1967 , federallysubsidized public housing had some 660,000 units under management. ${ }^{21}$ This is only one per cent of the total housing stock, and about half of a single year's new private construction at current rates. Throughout its lifespan, the public housing program has added an average of only 20,000 units annually-far less than the annual increase in the number of low-income minority households. By no means all public housing units, moreover, have been available to nonwhites. Furthermore, even the minor contribution of public housing to the improved housing of racial minorities has been made chiefly within the boundaries of the central cities and rarely in the suburbs-further enhancing the development of the ghettos.

In the past several years, increased public concern for the housing of low- and moderate-income families has added some weapons to the federal armament-for the first time providing a modicum of encouragement to private effort to enter this previously unrewarding field. But the first of these new measures was not enacted until the early rg6os. In the interim the postwar housing boom, spurred by federal incentives to private enterprise, had produced many millions of new private dwellings in suburban areas-on terms which restricted them almost solely to whites. During this period, the housing needs of expanding Negro and other minority population were met chiefly by succession to the older, often decaying dwellings left behind in the central cities by whites moving to the new homes being built in the suburbs.

The Housing Act of Ig6I initiated a new form of federal encouragement to private construction of housing for families unable to pay normal private-market rates. This is the FHA $22 \mathrm{I}$ (d) (3) "below-market-interest-rate" program. ${ }^{22}$ It lowers housing costs through direct purchase of mortgages by the Federal National Mortgage Association at interest rates considerably below those demanded by private lenders. Currently, the maximum rate is three per cent. This interest-rate subsidy allows prices low enough to aid families above public-housing income maxima but under private housing levels. Many minority families are in this previously-unaided category.

The program has been slow to get underway, however. Six years after its estab-

\footnotetext{
${ }^{20} 42$ U.S.C. $\$ \$ 140 \mathrm{I}-30$ (I964, Supp. II, I965-66).

21 This figure was supplied by the U.S. Housing Assistance Administration, Dep't of Housing and Urban Development.

${ }^{22}$ I2 U.S.C. $\$ I_{7}{ }_{5} l(d)(3)$ (Supp. II, I965-66).
} 
lishment, at the end of September 1967 , only 67,100 units had been insured. The present level of appropriation permits adding only about 40,000 units annually. ${ }^{23}$

The Housing Act of 1965 authorized still another form of assistance-direct rent supplements to owners of private housing to enable them to accommodate low-income families. ${ }^{24}$ This program for the first time permits low-income families to be integrated with those of somewhat higher incomes within the same housing development. The program was hotly contested in Congress, however; and despite its enactment no appropriations were forthcoming to implement it until fiscal year $1967-$ when the amount allocated was only $\$ 32$ million. ${ }^{25}$ Only $\$ 10$ million has been appropriated for the current fiscal year.

In fiscal year $196 \%$, and in a number of prior years, federal programs to aid private housing in combination generated more receipts than expenditures-placing them among very few federal programs which show a "profit." (Premiums charged for insurance and sales of acquired properties and mortgages account for most of this.) Few better commentaries could be made on the degree to which these programs have helped meet the housing needs of those citizens unable to bear the full market price. $^{2 b}$ The excess of receipts over expenditures in these federal aids to private housing was so great (\$1 37 million) as to erase more than half of the \$200 million spent by the federal government on subsidies for public housing in the same year.

It has already been suggested that there was a geographic concomitant to the racial and economic selectivity of federal housing programs. To state this geographic factor more fully and explicitly, the new private housing stimulated by federal policies was built chiefly on the open land available on the suburban fringes of the expanding metropolitan areas. The fact that this housing was not available to the great majority of Negroes meant, perforce, that the suburbs became almost exclusively white.

Simultaneously, the expanding housing needs of the Negro populations within the central cities were met (however inadequately) within the central cities, in dwellings left behind by departing whites. Private speculators and "blockbusting" real estate brokers aided the process of racial conversion to their personal profit. The public housing program, limited as it was in magnitude, further enhanced the trend of segregation by the fact that, where it made dwellings available to Negroes, these were generally located in central areas already heavily nonwhite in composition.

The federally-supported urban renewal program, initiated under the Housing Act of $1949,{ }^{27}$ was a foresighted effort to retain and restore the economic viability of central urban areas by encouraging more affluent segments of the population to

\footnotetext{
${ }^{28}$ This figure was supplied by the U.S. Federal Housing Administration, Dep't of Housing and Urban Development.

${ }^{34}$ I2 U.S.C. $\$$ I70Is (Supp. II, I965-66).

25 This figure was supplied by the U.S. Dep't of Housing and Urban Development.

${ }^{20}$ See U.S. BurEaU of THE Budget, supra note 17 .

${ }^{27}$ Ch. $33^{8}, 63$ Stat. $4^{1} 3$ (codified in scattered sections of 12,42 U.S.C.).
} 
return. It did this by providing federal subsidies for the acquisition, clearance, and resale to private developers of blighted urban areas. From its inception, the urban renewal program was administered with more sensitivity to the problem of racial discrimination than most other federal housing activities. As a consequence, a number of urban renewal projects provided the first racially-unsegregated private housing in their localities.

Nonetheless, the relatively high price levels of most urban renewal dwellings effectively excluded all but a tiny majority of nonwhites from residence. And since they were often located in areas formerly occupied by nonwhite slums, many such projects merely resulted in opening a small white (or nearly white) hole in the central Negro ghetto, while simultaneously causing the external boundaries of that ghetto to expand still further outward. ${ }^{28}$

To sum up, federal housing policy encouraged the growth of the ghettos in two main ways. First, during the major part of the postwar housing boom, federal benefits were largely restricted to whites for both economic and racial reasons; as we have indicated, the economic selectivity was by far the more important. Second, the geographic location of new federally-stimulated construction was such as to enhance segregation by drawing whites out of the central cities toward the suburbs, and permitting the areas they left behind to be occupied by Negroes. Only in the early I96os, after a decade and a half during which the all-white suburbs and their counterpart central-city Negro ghettos had grown to a point where they presented the nation with a domestic problem of frightening scope and complexity, were federal policies modified. These modifications were in two directions: first of all, to restrict racial discrimination in application of the federal benefits; and second, to assist private developers to serve a wider socioeconomic range. Even then, the measures were so limited in scope that they could not conceivably halt, let alone reverse, the now well-established tide of ghettoization.

Is it too late to undo what has been done? To believe that the point of no return has been passed is to accept the alternatives which have been outlined on preceding pages. It may also be to accept the loss of many of America's most highly cherished democratic protections. Already efforts to repress ghetto violence are producing legislation and police procedures which, carried to their logical extreme, could transform a free nation into a police state. Ultimately, the majority may suffer as much as the minority from the end effects of continued ghettoization and racial conflict.

Would the dissolution of ghetto patterns require forced redistribution of population? In answer, it is only necessary to point out that about half of all American households changed their place of residence during the latter half of the I950s

\footnotetext{
${ }^{28}$ This problem is discussed in E. Grier and G. Grier, Federal Powers in Housing Affecting Race Relations, Sept. I962 (an unpublished paper prepared for the Potomac Institute and the Washington Center for Metropolitan Studies).
} 
alone. Residential mobility is so much a part of the "American way of life" that a virtually complete redistribution of the population can easily be achieved within the span of a single generation, and without forcing anyone to move.

Such a massive redistribution has, in fact, largely been accomplished during the two decades since the conclusion of World War II. It has resulted in the present ghettoized pattern. The ultimate form of any future redistribution will depend largely upon the federal incentives which are applied to shape it. Continuation of present incentive patterns can only lead to the further growth of segregation.

What alterations in the pattern of federal benefits would accomplish the elimination of segregated residential patterns most effectively and economically? This question requires further study, and determination of the best means should be an objective of highest federal priority. But it is probable that measures recently placed on the books point the way. More flexible federal benefits; incentive programs which encourage private enterprise to produce housing for lower-income groups; measures which encourage racial and socioeconomic diversity both within particular housing developments and throughout entire metropolitan areas; measures which free housing subsidies from restriction to dwellings in control of public housing authorities or (as in the section $22 \mathrm{I}$ (d) (3) program) of non-profit sponsors; strengthened prohibitions against discrimination-these appear to constitute the most promising routes for federal intervention. Above all, it will be necessary for far greater funds to be allocated to assist families presently unable to compete in the private market.

These measures in the housing field must, of course, be accompanied by programs to improve the economic capability of minority groups and to overcome the manifold social deficits resulting from generations of selective disadvantage. The end goal of all such programs must, however, be to enable Negroes to take their place in the mainstream of American life-not to solidify the structure of the ghettos. The cost of adequate efforts will be high, but must be measured against the alternatives. There is little question that they are affordable, especially in light of the tremendous expenditures which accompanied the redistribution just accomplished.

Finally, and certainly not least, it will be necessary for the more fortunate white majority to learn to accept racial integration as desirable and, indeed, essential in every area of life. This will require fundamental reorientation of the values and biases which contributed to the direction of present federal policies. Can a democratic nation achieve such a redirection? This is the final unanswered question. Upon the nation's ability to face it and to answer it may rest its own survival. 